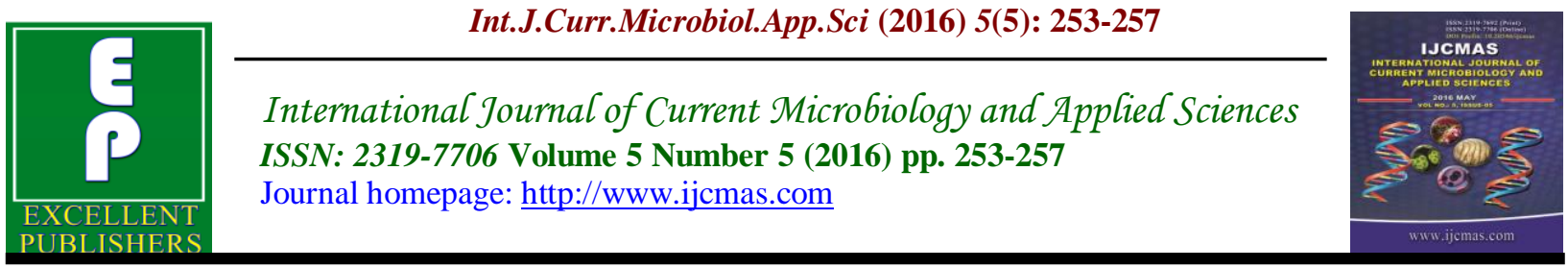

Original Research Article

http://dx.doi.org/10.20546/ijcmas.2016.505.027

\title{
Comparative Study of Antioxidant Nature in Curry Patta, Garlic, Onion, Ginger and Turmeric Herbal Plants
}

\author{
Ajay Singh* and Vipin Panwar \\ Department of Chemistry, Uttaranchal University, Dehradun, Uttarakhand, India \\ *Corresponding author
}

\begin{abstract}
A B S T R A C T
Keywords

Antioxidant,

Enzymatic,

Non-Enzymatic

Activity, Essential

Oils, Murraya

Koengii, Citrus

Maxima and

Ananas Comosus.

\section{Article Info}

Accepted:

12 April 2016

Available Online:

10 May 2016

Antioxidant compounds suppress the free radicals generated in our body due to different biological functions. Generally grains, fruits, vegetables are considered primary sources of naturally occurring antioxidants but some herbal spices like garlic, curry patta, ginger are also source of antioxidant. Antioxidant compounds are found in the extracts or essential oils of the plants. Essential oils contain terpenes, alcohols, esters, aldehydes, ketones and phenolic compounds which are responsible for antioxidant, antimicrobial and antihistaminic properties. In the present study essential oils and extracts of curry patta, garlic, onion, ginger and turmeric were taken. Enzymatic and non-enzymatic antioxidant activities were determined in extracts of these selected herbal plants. Estimation of antioxidant activities were carried out by $\beta$-carotene bleaching method, thiocyanate assay \& deoxyribose assay methods. All plant essential oils showed antioxidant activity at low and moderate concentration in thiocyanate assay. The maximum antioxidant nature was shown by chakotra followed by pine apple and curry patta. In deoxyribose assay all plant essential oils showed antioxidant activity at lower concentration. Curry patta showed the maximum activity followed by chakotra and pine apple. In $\beta$-carotene bleaching method, Chakotra essential oils showed maximum antioxidant activity.
\end{abstract}

\section{Introduction}

Antioxidants are the compounds which suppress the free radicals generated in our body due to different biological functions. Antioxidants are substances that reduce, neutralize, and prevent the damage done to the body by free radicals. Free radicals are the species containing simply electrons that are no longer attached to atoms. Instead of circling the nucleus of an atom (much like the earth circles the sun), free radicals are both free and radical enough to go careening through our cells (Meister, 1994). A process called oxidation creates free radicals and this process happens in the context of normal metabolic processes and our everyday exposure to our environment. In other words, eating, breathing, and going out in the sun all contribute to the process of oxidation, free radical formation, and the resulting damage that is caused to the cells of our bodies. It causes the deterioration of bone, joints and connective tissue; the 
wearing out of organs; the decline of the immune system; the irritating advance of the visible effects of aging; and even, possibly, to some extent, the aging process itself (Padayatty et al., 2003). Various types of food taken by the body play an important role as a health-protecting factor. Antioxidants reduce the risk for chronic diseases including cancer and heart disease. Primary sources of naturally occurring antioxidants are whole grains, fruits, vegetables etc. Some herbal spices like garlic, curry patta, ginger are also source of antioxidant. Antioxidant compounds are found in the extracts or essential oils of the plants. The chemical compounds which are obtained by odoriferous essences extracted from various parts of plants are known as essential oils. Essential oils contain terpenes, alcohols, esters, aldehydes, ketones and phenolic compounds which show antioxidant, antimicrobial, and antihistaminic properties. Citrus fruits are notable for their fragrance or essence, partly due to flavonoids and limonoids contained in the rind, and most are juiceladen(German, 1999). The juice contains a high quantity of citric acid giving them their characteristic sharp flavor. They are also good sources of vitamin $\mathrm{C}$ and flavonoids. (Knight, 1998)..Essential oils are used as flavouring agent or disinfectant or as perfume in food industry, perfume or pharma industry.

Citrus fruits are important source of bioactive compounds including antioxidants such as ascorbic acid, flavonoids, phenolic compounds and pectins that are important to human nutrition (Fernandez- Lopez et al., 2005; Jayaprakasha and Patil, 2007; Ebrahimzadeh et al., 2004). Flavanones, flavones and flavonols are three types of flavonoids which occur in Citrus fruits (Calabro et al., 2004). The main flavonoids found in citrus species are hesperidine, narirutin, naringin and eriocitrin (Mouly et al., 1994; Schieber et al., 2001).

Early research on the role of antioxidants in biology focused on their use in preventing the oxidation of unsaturated fats, which is the cause of rancidity. Antioxidant activity could be measured simply by placing the fat in a closed container with oxygen and measuring the rate of oxygen consumption. However, it was the identification of vitamins $\mathrm{A}, \mathrm{C}$, and $\mathrm{E}$ as antioxidants that revolutionized the field and led to the realization of the importance of antioxidants in biochemistry of living organisms (Jeffrey, 1986).

Much like the immune system itself, which operates at a cellular level, the hardworking vitamin $\mathrm{C}$ reaches every cell of the body. The concentration of vitamin $\mathrm{C}$ in both blood serum and tissues is quite high. In fact, this nutrient plays a major role in the manufacture and defence of our connective tissue, the elaborate matrix that holds the body together. It serves as a primary ingredient of collagen, a glue-like substance that binds cells together to form tissues (Padayatty et al., 2003). As a water-soluble antioxidant, vitamin $\mathrm{C}$ is in a unique position to "scavenge" aqueous proxy radicals before these destructive substances have a chance to damage the lipids. It works along with vitamin $\mathrm{E}$, a fat-soluble antioxidant, and the enzyme glutathione peroxidase to stop free radical chain reactions. (Valco et al., 2007).

\section{Materials and Methods}

\section{Material}

Leaves of curry patta were collected from FRI-Dehradun while garlic, onion, ginger and turmeric were collected from local market of Dehradun. Essential oils were 
extracted from curry patta by using Clevenger assembly. Other materials( garlic, ginger, onion and turmeric) were peeled off. After peeling juice was extracted with the help of juicer \& mixer in laboratory. Equal volume of the juices was taken and mixes it with $50 \%$ ethanol. It was centrifuged at 5000 rpm for 10 minutes. Supernatant was separated and pellet was discarded. Essential oil \& supernatant liquid was used for estimation of antioxidant activity. Protein content was estimated by using Lowry's method \& Bradford Method taken from Singh \& Sawhney's introductory practical Biochemistry book (Sawhney and Singh, 2007).

\section{Enzymatic Antioxidant Activity: Superoxide Dismutase (SOD) Activity Assay}

In this method four solutions $\mathrm{A}, \mathrm{B}, \mathrm{C} \& \mathrm{D}$ were prepared.

Solution A: $0.1 \mathrm{mM}$ EDTA containing $50 \mathrm{mM} \mathrm{Na} \mathrm{NO}_{3}$.

Solution B: $90 \mu \mathrm{M}$ Nitroblue tetrazolium in solution A.

Solution C: $0.6 \%$ triton $\mathrm{X}$ in solution $\mathrm{A}$.

Solution D: $20 \mathrm{mM}$ hydroxylamine $\mathrm{HCl}$ (pH-6)

In the test tubes, $1.3 \mathrm{ml}$ of solution $\mathrm{A}$ and $0.5 \mathrm{ml}$ solution $\mathrm{B}$ then $0.1 \mathrm{ml}$ of solution $\mathrm{C}$ and $0.1 \mathrm{ml}$ of solution $\mathrm{D}$ were added to the tubes and mixed well. $5 \mu 1$ juice extract was added to that reagent mixture and immediately absorbance at 560nm at interval of 20 second was taken. SOD was calculated. Estimation of ascorbic acid (Vitamin C) of samples done by using method given in Sawhney and Singh (2007).

\section{$\beta$-Carotene Bleaching Method}

In this procedure the plant extracts or essential oil, Vitamin E and BHA (butylated hydroxy anisole) were applied on TLC plates and after developing with a suitable solvent system, plates were sprayed with a betacarotene solution and exposed to daylight until discoloring of the background (6hrs.) The active compounds were seen as orange color on the plate. Methanolic extracts of Citrus plants, Vitamin $\mathrm{E}$ and BHA were used as positive controls. Extracts which showed strong antioxidant activity were subjected to further tests. The same experiment was performed for the isolated fractions and compounds.

\section{Thiocyanate Assay}

The peroxy radical scavenging activity was determined by thiocyanate method using vit. $\mathrm{C}$ as standard. Increasing concentration of the fractions in $0.5 \mathrm{ml}$ of distilled water was mixed with $2.5 \mathrm{ml}$ of $0.02 \mathrm{M}$ linoleic acid emulsion (in $0.04 \mathrm{M}$ phosphate buffer $\mathrm{pH}$ $7.0)$ and $2 \mathrm{ml}$ phosphate buffer $(0.04 \mathrm{M}, \mathrm{pH}$ 7 ) in a test tube and incubated in darkness at 37oC. At intervals during incubation, the amount of peroxide formed was determined by reading the absorbance of the red colour developed at $500 \mathrm{~nm}$ by the addition of 0.1 $\mathrm{ml}$ of $30 \%$ ammonium thiocyanate solution and $0.1 \mathrm{ml}$ of $20 \mathrm{mM}$ ferrous chloride in $3.5 \%$ hydrochloric acid to the reaction mixture. The percentages scavenging inhibitions was calculated and were compared with the standard, Ascorbic acid. A control was also prepared replacing water with plant extract and essential oil.

Experimental results of protein content in samples are given in Table-1, Ascorbic acid and \& SOD activities are given in Table-2, antioxidant activities by $\beta$-carotene bleaching method are given in table-3.

\section{Results and Discussion}

From above table, it can be estimated that for $1 \mathrm{ml}$ juice, $3.97 \mathrm{gm}$ of curry patta, 4.17 
gm of ginger and 4.09 of garlic, $4.03 \mathrm{~g}$ of onion \& $4.06 \mathrm{gm}$ of turmeric was needed. Curry patta was found to have maximum protein content i.e. $29.5 \mu \mathrm{g} / \mathrm{ml}$, followed by garlic and turmeric.

Table.1 Protein Content in Samples

\begin{tabular}{|l|c|c|c|r|}
\hline S.No. & Samples & $\begin{array}{c}\text { Wt. of sample for } \\
\mathbf{1 m l} \text { of juice }(\mathbf{g m s})\end{array}$ & $\begin{array}{c}\text { Protein in Juice } \\
\text { Extract } \boldsymbol{\mu g} / \mathbf{m l}\end{array}$ & $\begin{array}{c}\text { Protein in sample } \\
\boldsymbol{\mu g} \mathbf{g m}\end{array}$ \\
\hline 1. & Curry Patta & $50 / 12.6=3.97$ & 118 & $118 / 3.97=29.5$ \\
\hline $2 .$. & Ginger & $50 / 12=4.17$ & 119 & $119 / 4.17=28.53$ \\
\hline $3 .$. & Garlic & $50 / 12.2=4.09$ & 120 & $120 / 4.09=29.3$ \\
\hline 4. & Onion & $50 / 12.4=4.03$ & 114 & $114 / 4.03=28.28$ \\
\hline 5. & Turmeric & $50 / 12.3=4.065$ & 118 & $118 / 4.06=29.03$ \\
\hline
\end{tabular}

Table.2 Ascorbic Acid \& SOD in Plant Samples

\begin{tabular}{|c|c|c|c|c|}
\hline S.No. & $\begin{array}{c}\text { Plant } \\
\text { Sample }\end{array}$ & $\begin{array}{c}\text { SOD } \\
\text { Activity(unit/mg) }\end{array}$ & $\begin{array}{c}\text { Ascorbic acid } \\
\text { mg/ml of juice }\end{array}$ & $\begin{array}{c}\text { Ascorbic acid in per } \\
\text { gram of sample }\end{array}$ \\
\hline 1. & Curry Patta & $\mathbf{1 8 . 5}$ & $\mathbf{0 . 6 5}$ & $\mathbf{0 . 6 5 / 3 . 9 7}=\mathbf{0 . 1 6}$ \\
\hline 2. & Ginger & 18.7 & 0.62 & $0.62 / 4.17=0.14$ \\
\hline 3. & Garlic & 18.9 & 0.63 & $0.63 / 4.09=0.154$ \\
\hline 4. & Onion & 18.0 & 0.60 & $0.60 / 4.03=0.149$ \\
\hline 5. & Turmeric & 18.6 & 0.61 & $0.61 / 4.06=0.150$ \\
\hline
\end{tabular}

Table.3 Antioxidant Activity by b-carotene Bleaching Method

\begin{tabular}{|c|c|c|c|}
\hline S.N & Fruit Sample & $\begin{array}{l}\text { Antioxidant activity } \\
\text { when Quantity of } \\
\text { essential oil }-10 \mu \mathrm{L}\end{array}$ & $\begin{array}{l}\text { Antioxidant } \\
\text { activity when } \\
\text { Quantity } \\
\text { essential oil - } 20 \mu \mathrm{L}\end{array}$ \\
\hline 1 & Curry Patta & 69.3 & 72.0 \\
\hline 2 & Ginger & 70.4 & 72.9 \\
\hline 3 & Garlic & 68.3 & 70.0 \\
\hline 4 & Onion & 67.2 & 69.5 \\
\hline 5. & Turmeric & 69.1 & 71.9 \\
\hline
\end{tabular}

Enzymatic antioxidant property: Superoxide dismutase was found to be maximum in garlic (18.9unit/mg of protein) followed by ginger (18.7 unit/mg) and turmeric(18.6 unit/mg). Ascorbic acid was observed maximum in curry patta $(0.65 \mathrm{mg} / \mathrm{ml})$ followed by garlic $(0.62 \mathrm{mg} / \mathrm{ml})$. Ascorbic acid on the basis of weight of sample taken was also observed maximum in curry patta then in ginger and turmeric. (Table 2). Results observerd by Ajay singh et al., also supports our study. Antioxidant property of citrus fruits is mainly due to vitamin $\mathrm{C}$ (ascorbic acid), terpenes like limonene and flavonoids compounds. The results reported by Gavy and Singh also support our findings (Padayatty et al., 2003).

\section{$\beta$-Carotene Bleaching Method}

Antioxidant activity by $\beta$-carotene bleaching method was determined by taking $10 \& 20$ 
$\mu \mathrm{L}$ of essential oils. Results are given in Table-3, in this method, Ginger has shown maximum activity followed by curry patta $\&$ turmeric. Similar trend was obtained when concentration of essential oil was increased upto $20 \mu \mathrm{L}$. but on very high oil concentration, antioxidant property might vary. Thiocyanate method also showed that ginger has max antioxidant property.

\section{References}

Ajay Singh, et al. 2008. Studies on antimicrobial and antioxidant activities of Allium sativum, Allium cepa and Citrus limon, Phytochemicals: a therapeutant for critical disease management, pp. 277292.

Ajay Singh, Harish Chandra. 2011. Comparative studies on the antimicrobial activities of garlic, onion and lemon: individual and combined, NPAIJ, 7(3): p 101-109.

Ajay Singh, G., Awasthi, Deepak, Harish Chandra, Rawat, M.S.M. 2007. Studies on Antioxidant Activities of Garlic(Allium Sativum), Onion (Allium Cepa) and Lemon (Citrus Limon). Universities J. Phytochemistry and Ayurvedic heights, Vol2 No.3, pg.45-48.

German, J. 1999. "Food processing and lipid oxidation". Adv. Exp. Med. Biol., 459: $23-50$.
Knight, J. 1998. "Free radicals: their history and current status in aging and disease". Ann. Clin. Lab. Sci., 28(6): 331-46.

Jacob, R. 1996. Three eras of vitamin C discovery. Subcell Biochem., 25: 116.

Meister, A. 1994. Glutathione-ascorbic acid antioxidant system in animals. J. Biol. Chem., 269(13): 9397 - 400.

Gaby, S.K., Singh, V.N.Vitamin C,Vitamin Intake and Health: A Scientific Review.

Padayatty, S., Katz, A., Wang, Y., Eck, P., Kwon, O., Lee, J., Chen, S., Corpe, C., Dutta, A., Dutta, S., Levine, M. 2003. "Vitamin C as an antioxidant: evaluation of its role in disease prevention". J. Am. Coll. Nutr., 22(1): $18-33$.

Jeffrey Bland. 1986. The Nutritional Effects of Free Radical Pathology: 1966/A Year in Nutritional Medicine, Keats Publishing Inc., New Canaan, CT, p. 16.

Valko, M., Leibfritz, D., Moncol, J., Cronin, M., Mazur, M., Telser, J. 2007. Free radicals and antioxidants in normal physiological functions and human disease. Int. J. Biochem. Cell Biol., 39(1): 44-84.

Sawhney Randhir Singh, S.K. 2007. Introductory practical biochemistry, Fifth Reprint.

\section{How to cite this article:}

Ajay Singh and Vipin Panwar. 2016. Comparative Study of Antioxidant Nature in Curry Patta, Garlic, Onion, Ginger and Turmeric Herbal Plants. Int.J.Curr.Microbiol.App.Sci. 5(5): 253257. doi: http://dx.doi.org/10.20546/ijcmas.2016.505.027 